\title{
Understanding Employees' Preferences: Their Work Values, Environment, Interaction and Activities
}

\author{
Emeliza Torrento Estimo, Geneveve Mandado Aguilar \\ Research Department, John B. Lacson Colleges Foundation, Bacolod City, Philippines \\ Email address: \\ emeliza.estimo@jblfmu.edu.ph (E. T. Estimo),geneveve.aguilar@jblfmu.edu.ph (G. M. Aguilar)
}

\section{To cite this article:}

Emeliza Torrento Estimo, Geneveve Mandado Aguilar. Aguilar. Understanding Employees' Preferences: Their Work Values, Environment, Interaction and Activities. Science Journal of Education. Vol. 5, No. 6, 2017, pp. 236-243. doi: 10.11648/j.sjedu.20170506.12

Received: October 14, 2017; Accepted: October 30, 2017; Published: December 12, 2017

\begin{abstract}
This descriptive study aimed to find out the preferred work values, environment, interactions, and activities of employees in a Maritime institution. A survey questionnaire was administered to a group of respondents composed of 146 faculty and non-teaching staff who represent the sample size from the total population of 231 employees. Results of the study showed evidence that the employees place the highest value on spirituality, mutual respect, reaching goals, open communication, strong support system, cohesiveness, effective leadership, transparency, and recognition, among others. As a whole, they respond most positively to a fast-paced, result-oriented, and organized work environment. Building from the findings gathered, the study recommends the alignment of the employees' preferences with the institution's core values and priorities. Since being recognized for their efforts and contribution is important to them, recognition must be given where and when it is deemed best. It is also recommended that more workshops must be held to provide the employees an opportunity to revisit their value system in relation to themselves and others in the organization. Priorities in relation to work must also be reassessed or redefined through these workshops.
\end{abstract}

Keywords: Institutional Research, Work Values, Work Environment, Work Interaction and Work Activities

\section{Introduction}

Initiatives to include human considerations are mobilized in educational institutions to include inculcating values and motivations that bring about environmentally responsible behavior [1]. Universities teach notions of norms and behaviors that add to "good," sustainable lifestyles [2] and as such, certain sets of value systems become part of the formation for all the members of the academic community, teachers, administration, and students alike. Values are often heard side by side with the school's vision, mission statement, and culture. According to Urde [3], wellestablished and maintained core values influence all kinds of decisions within organizations.

Core values are traits or qualities that are considered worthwhile because they represent an individual's or the organization's highest priorities, deeply held beliefs, and core, fundamental driving forces. Urde [3] further explains that core values need to be monitored and maintained. Employees should be provided with a positive work environment. A positive work environment makes them feel good about coming to work every day. It provides them something to look forward to no matter how hard and challenging the work is.

Employees also need to be provided with an atmosphere where they can interact smoothly with others in the organization. A positive work interaction breeds a positive and a healthy environment. It enhances employee commitment, performance, motivation, and empowerment. In an effective organization, employees are well-informed about the future directions of the organization and are considered important in decision-making processes [4]. This type of system combines upward and downward communication that is of particular importance during processes of organizational change to get employees to commit to the change and to make the change happen. Moreover, interactive processes are an essential feature of a sustainable communication [5].

The employees of educational institutions will all the more be happy and productive if the work activities assigned to 
them would suit their abilities and capabilities as well as their preferences. It is ideally necessary that what is provided in the work environment must address those that the employees prefer to perform aside from their primary functions as educators and office personnel.

Several studies have tried to explain the influential roles of particular factors on employees' productivity and creativity at work. For instance, people will be most creative when they feel motivated primarily by their interest, satisfaction, and challenge of the work itself. Organizational creativity begins with creative people and stems from the ability to do what you love and love what you do [6]. Support and encouragement of managers and colleagues, social admiration, and recognition are significant factors that trigger their creativity [7]. Moreover, spirituality could enhance personal well-being and could influence creativity in terms of motivation, social support and intention, and receptivity. Tapping into the employees' spiritual intelligence could enhance creativity, motivation, and performance [8].

Furthermore, several researchers have discovered possible influence to employees' characteristics of certain variables like gender, age, tenure, and nature of work. For instance, it was found out that there is a statistically significant difference in the behavioral, emotional and overall organizational involvement of male and female workers. In addition, female workers show higher emotional and cognitive involvement than their male counterparts and that employees whose tenure was over five years are more emotionally involved than those who are younger in the organization [9]. It was also found out that younger employees show less involvement and less organizational commitment than their middle and elderly age group counterparts [10]. Gender and maturity (a combination of age and educational level) were also proven to be predictors of idealized styles of leadership. Employees with higher levels of education and greater job tenure expressed less preference for leader structuring (task-oriented behaviors). Women (relative to men) showed a higher preference for leader considerateness (relationship-oriented behaviors) [11]. Furthermore, it was discovered that men and women prefer to approach work differently in that a higher percentage of women than men prefer to perform specific work activities that are directly identified with the organizations' products or services. On the other hand, a greater percentage of men than women prefer to initiate organizational level activities and perform work activities identifiable with the organizational goals and results [12].

Inspired by these studies relating to employees in the workplace, the researchers of this study tried to look into work situations preferred by the employees of a maritime institution, one of the three academic campuses of a maritime university in the Philippines. The University as a leading maritime institution in the country places a high value on the importance of values formation and in sustaining its workforce. As such, the University includes among its NinePoint Agenda, Agendum No. 5 (Inculcation of Values) and 8 (A Competent and Productive Workforce). It upholds the core values of perseverance, loyalty, excellence, discipline, Godliness, and equality (PLEDGE) and maximizes its efforts to ensure that all the employees are happy and contented with their work and with all the other factors that exist in the workplace such as their work environment, work interaction, and other activities assigned to them; hence, this study.

\subsection{Framework}

This study is anchored on Frederick Herzberg's TwoFactor Theory espoused by Robbins [13] that names two sets of factors in deciding work attitudes and job performance in the workplace---Motivation and Hygiene Factors. Motivation factors are intrinsic factors that increase job satisfaction, while Hygiene Factors are those that prevent employees' dissatisfaction. According to this theory, to satisfy employees, higher level needs (intrinsic or motivation factors) must be supplied. Furthermore, this theory explains that extrinsic factors or job context factors do not necessarily contribute to employees' motivation but could prevent dissatisfaction in the workplace. These factors provide a favorable work environment where employees feel comfortable working in. While intrinsic and extrinsic factors as espoused by Herzberg influence the employees' preferences in terms of work values, environment, interaction, and activities, these preferences also shape the kind of attitude and performance they manifest at work. Employers should obtain a clear understanding of their employees' dissimilarities in needs and preferences for motivation factors to boost up their performance towards overall organizational goal.

Work values are personal standards that are highly esteemed by an individual and are related to all aspects of one's personal and work life. Although there are contentions that these characteristics are innate, 'preferred work values' in this study are those that employees consider as crucial elements in the context of their workplace. The parameters set for determining the employees' preferred work values, environment, interaction, and activities were patterned from several readings on work values inventories but leaned much on the Work Values Inventory designed by Santa Cruz County Regional Occupational Program (ROP) which provides people with the opportunity to examine their preferences. Preferences on work values can be based on achievement, balance, independence, influence, integrity, honesty, power, respect, spirituality, and status, depending on what constitutes the highest value in an employee's hierarchy of choice. Work Environment can be characterized as fastpaced, flexible, high earning, learning-oriented, accessible, predictable, quiet, relaxed, structured, and time-free. Work Interaction can be described by its leaning towards competition, diversity, friendship, leadership, management, open communication, recognition, support, teamwork, and trust. Finally, work activities can be analytical, challenging, creative, helping, leading edge, physical, requires public contact, research-oriented, risk-taking, and multi-varied. These concepts are expressed in the following diagram: 


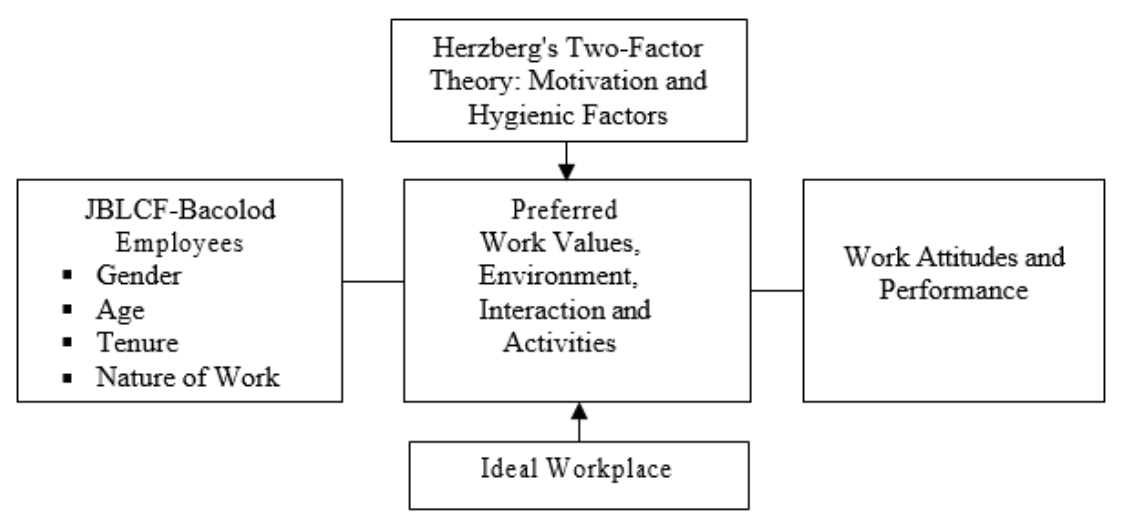

Figure 1. Schematic Diagram.

\subsection{Research Problems}

This study aimed to find out and compare the work values, environment, interactions, and activities preferred by the employees as they perform their work and interact with others in the organization. Specifically, the study sought to address the following questions:

1. What are on top of the preferences of the faculty and non-teaching staff when taken as a whole in terms of the following aspects?

a. Work Values

b. Work Environment

c. Work Interactions

d. Work Activities

2. Do the preferences of the employees in terms of work values, work environment, work interactions and work activities vary when they are grouped according to gender, age, tenure, and nature of work?

3. How do the employees describe their ideal work environment?

\section{Methods}

\subsection{Research Design}

The descriptive design using survey method was used in this study. This design ensures that the evidence obtained enables one to effectively address the research problem as unambiguously as possible. It involves gathering data that describe events and then organizes, tabulates, depicts, and describes the data collected [14].

\subsection{Respondents}

The respondents of the study were composed of 146 employees who represent the sample size from the total population of 231 employees. This sample size comprised 85 faculty and 61 non-teaching staff.

\subsection{Research Instrument}

A researcher-made survey questionnaire was used in this study. The first part of the instrument was designed to obtain the profile of the respondents based on the variables considered, i.e., gender, age, tenure, and workgroup (nature of work). The main portion of the survey questionnaire was divided into four parts where the respondents were asked to rate their preferred core work values, environment, atmosphere, and activities using a four-point Likert Scale. The instrument also contained an open-ended question asking the respondents to describe their "ideal workplace." Face and content validity were obtained by submitting the questionnaire to a jury of experts who commented on some ways to improve the construction of the items. Cronbach's alpha was used to test the reliability of the instrument which obtained an alpha coefficient of 0.92 , interpreted as excellent [15] [16]. This survey questionnaire was used to gather the data needed for the study.

\subsection{Statistical Tools}

To address problem 1, the mean and rank were used while t-test and Analysis of Variance were employed to answer problem 2. The means obtained were interpreted using the following scale, verbal interpretation, and descriptive value:

Table 1. Scale for the interpretation of the mean.

\begin{tabular}{lll}
\hline Mean Range & Interpretation & Descriptive Value \\
\hline $3.25-4.00$ & Very Important & Always Valued \\
$2.50-3.24$ & Important & Valued Most of the Time \\
$1.75-2.49$ & Sort of Important & Valued Occasionally \\
$1.00-1.74$ & Not Important & Given the Least Value \\
\hline
\end{tabular}

\section{Results}

The employees have varied preferences in terms of work values, work environment, work interaction and work activities. These are shown in the following tables.

\subsection{Preferred Work Values, Environment, Interactions and Activities by the Employees When Taken as a Whole}

\subsubsection{Work Values}

Table 2 reports that the employees place a very high value on spirituality, mutual respect, reaching goals, truth and propriety, openness, and balance between family, work, and pleasure. These findings, with spirituality on top, support the 
contentions made by Steve [8] on the value of spirituality as an intrinsic factor that could enhance personal well-being and creativity in terms of motivation, social support and intention, and receptivity.

Table 2. Preferred work values by the employees.

\begin{tabular}{lllll}
\hline Work Values & Mean & SD & Rank & Interpretation \\
\hline Achievement & 3.71 & 0.47 & 3 & Very Important \\
Balance & 3.66 & 0.47 & 5 & Very Important \\
Independence & 3.62 & 0.55 & 7 & Very Important \\
Influence & 3.34 & 0.66 & 8.5 & Very Important \\
Integrity & 3.64 & 0.52 & 6 & Very Important \\
Honesty & 3.67 & 0.67 & 4 & Very Important \\
Power & 2.94 & 0.77 & 10 & Important \\
Respect & 3.73 & 0.47 & 2 & Very Important \\
Spirituality & 3.86 & 0.34 & 1 & Very Important \\
Status & 3.34 & 0.76 & 8.5 & Very Important \\
Total & 3.55 & 0.64 & & Very Important \\
\hline
\end{tabular}

\subsubsection{Work Environment}

The employees respond most positively to a fast-paced result-oriented, and organized work environment that is accessible and convenient and one that could offer them financial opportunities and stability. Moreover, they place a high value on trust, open communication, and friendship. The rest of the results are shown in Table 3.

Table 3. Preferred work environment by the employees.

\begin{tabular}{lllll}
\hline Work Environment & Mean & sd & Rank & Interpretation \\
\hline $\begin{array}{l}\text { Fast-paced and result- } \\
\text { oriented }\end{array}$ & 3.63 & 0.51 & 1 & Very Important \\
Flexible & 3.14 & 0.77 & 10 & Important \\
High Earning & 3.40 & 2.56 & 5 & Very Important \\
Learning & 3.58 & 0.52 & 2 & Very Important \\
Location & 3.51 & 0.57 & 3 & Very Important \\
Predictable & 3.31 & 0.72 & 7.5 & Very Important \\
Quite & 3.34 & 0.65 & 6 & Very Important \\
Relaxed & 3.15 & 0.76 & 9 & Important \\
Structured & 3.50 & 0.52 & 4 & Very Important \\
Time Freedom & 3.31 & 0.75 & 7.5 & Very Important \\
Total & 3.39 & 1.03 & & Very Important \\
\hline
\end{tabular}

\subsubsection{Work Interaction}

The preferred work interaction of the employees as presented in Table 4 is characterized by a strong support system and cohesiveness and of working together for the attainment of a common goal.

Table 4. Preferred work interaction by the employees.

\begin{tabular}{lllll}
\hline Work Interaction & Mean & SD & Rank & Interpretation \\
\hline Competition & 2.59 & 0.91 & 10 & Important \\
Diversity & 3.10 & 0.68 & 9 & Important \\
Friendship & 3.38 & 0.76 & 8 & Very Important \\
Leadership & 3.65 & 0.59 & 4 & Very Important \\
Management & 3.67 & 0.54 & 3 & Very Important \\
Open Communication & 3.42 & 0.65 & 7 & Very Important \\
Recognition & 3.59 & 0.63 & 5 & Very Important \\
Support & 3.70 & 0.54 & 2 & Very Important \\
Teamwork & 3.72 & 0.49 & 1 & Very Important \\
Trust & 3.57 & 0.66 & 6 & Very Important \\
Total & 3.44 & 0.74 & & Very Important \\
\hline
\end{tabular}

They respond best to effective leadership, and it is crucial for them that their efforts and contributions are acknowledged and recognized. Moreover, they consider it important that there is transparency where information is not held back from them by the administration, and that socialization is established with their co-workers. These findings corroborate those pointed out in Happiness Research: Benefits to Make Staff Happy [17] that place a high emphasis on social status, recognition, strong reward system, and the support and encouragement of managers and colleagues in the workplace.

\subsubsection{Work Activities}

Results in Table 5 reveal that the employees are best tuned in for work activities that allow creativity, sharing of ideas, skills, and talents, and bringing in innovative ideas to produce results. They are also best inclined towards analytical types of activities which engage them to seek continuously for new information and solutions. Knowing what the employees prefer to engage in terms of work activities is essential because, according to Amabile [6], people become most creative and motivated when they are interested, satisfied, and challenged by the work itself. Organizational creativity begins when people love what they are doing.

Table 5. Preferred work activities by the employees.

\begin{tabular}{lllll}
\hline Work Activities & Mean & SD & Rank & Interpretation \\
\hline Analytical & 3.38 & 0.61 & 5 & Very Important \\
Challenging & 3.36 & 0.69 & 6 & Very Important \\
Creative & 3.47 & 0.62 & 3 & Very Important \\
Helping & 3.65 & 0.51 & 1 & Very Important \\
Leading Edge & 3.48 & 0.61 & 2 & Very Important \\
Physical & 3.05 & 0.84 & 10 & Important \\
Public Contact & 3.26 & 0.67 & 8 & Very Important \\
Research & 3.42 & 0.66 & 4 & Very Important \\
Risk Taking & 3.20 & 0.75 & 9 & Important \\
Variety & 3.34 & 0.70 & 7 & Very Important \\
Total & 3.36 & 0.70 & & Very Important \\
\hline
\end{tabular}

\subsection{Work Values, Environment, Interaction and Activities of the Employees When Grouped According to Gender, Age, Tenure and Nature of Work}

\subsubsection{According to Gender}

Table 6 reveals that there is no significant difference in the preferences of the employees in terms of work values [ $t$ (144) $=-0.48, \mathrm{p}=.37]$ and work environment $[\mathrm{t}(144)=-4.07, \mathrm{p}=$ 0.09]. These findings indicate that both male and female employees attribute the same preference to the various indicators for work values and work environment.

On the other hand, a significant difference was noted in the preferences of male and female employees in terms of work interactions $[\mathrm{t}(144)=4.60, \mathrm{p}=0.00]$ and work activities $[\mathrm{t}$ $(144)=1.99, p=0.03]$. It can be said that the male employees express a higher preference to the various indicators of work interactions than their female counterparts. 
Table 6. Differences in the preferred work values, environment, interactions and activities of the employees when they are grouped according to gender.

\begin{tabular}{|c|c|c|c|c|c|c|}
\hline & Gender & Mean & SD & df & $t$ & $\mathbf{p}$ \\
\hline \multirow{2}{*}{ Work Values } & Male & 3.54 & 0.19 & \multirow{2}{*}{144} & \multirow{2}{*}{-0.48} & \multirow{2}{*}{0.37} \\
\hline & Female & 3.56 & 0.19 & & & \\
\hline \multirow{2}{*}{ Work Environment } & Male & 3.38 & 0.19 & \multirow{2}{*}{144} & \multirow{2}{*}{-4.07} & \multirow{2}{*}{0.09} \\
\hline & Female & 3.49 & 0.23 & & & \\
\hline \multirow{2}{*}{ Work Interaction } & Male & 3.50 & 0.13 & \multirow{2}{*}{144} & \multirow{2}{*}{4.60} & \multirow{2}{*}{$0.00 *$} \\
\hline & Female & 3.38 & 0.22 & & & \\
\hline \multirow{2}{*}{ Work Activities } & Male & 3.40 & 0.30 & \multirow{2}{*}{144} & \multirow{2}{*}{1.99} & \multirow{2}{*}{$0.03 *$} \\
\hline & Female & 3.32 & 0.22 & & & \\
\hline
\end{tabular}

*Significant at 0.05 alpha level of significance.

A more detailed analysis of the data on work values revealed that while both groups value spirituality on top of everything, male employees are very particular with protecting their self-image as evidenced by their preference for achievement, power, and status as well as on achieving a balance between family, work, and pleasure. Female employees, on the other hand, put more importance on those that are more "intrinsic" such as independence, integrity, honesty, and respect.

Both male and female groups prefer a work environment that is fast-paced and result-oriented, intellectually challenging, organized, and close to work while female employees prefer as second a work environment which has the potential to make much money. Male employees, in particular, choose a job environment that is intellectually challenging, organized, structured, convenient, accessible and predictable. While both groups interact best under good leadership and management and thrive best in relationships characterized by support, trust, and teamwork, male employees place a greater value on competition and diversity.

In addition, both groups are equally inclined to work activities that involve helping people, searching for new information, require working on new and innovative projects, and creativity. It is the male group, however, who significantly place a greater value for work activities that are analytical, challenging, involving public contact and risk-taking. Uniquely, it is the female group who place more value on work that implies a lot of physical activities.

\subsubsection{According to Age}

Results presented in Table 7 reveal that the preferences of the employees on work values $[\mathrm{F}(2,143)=3.94,0.02<0.05]$, environment $[\mathrm{F}(2,143)=5.58,0.01<0.05]$, interaction $[\mathrm{F}(2$, $143)=14.58,0.00<0.05]$, and activities $[\mathrm{F}(2,143)=20.51$, $0.00<0.05]$ significantly differ when they are grouped according to age. In addition, Post hoc comparisons using the Tukey HSD test indicated that on work values and work environment, it is the preferences of employees who belong to the oldest group (41 and above) that significantly differed far from the other age groups.

On work interaction, data showed that there is a significant difference between the mean scores of employees aging 31 to 40 years old and 20 to 30 years old; between 20 to 30 years old and 41 years old and above; and between 31 to 40 years old and 41 years old and above. It can be said that preferences on work interaction differ significantly across all age groups. This implies that employees tend to interact more effectively with colleagues who belong to the same age group.

Table 7. Differences in the preferred work values, environment, interactions and activities of the employees when they are grouped according to age.

\begin{tabular}{|c|c|c|c|c|c|}
\hline & Age & Mean & SD & $F_{(2,143)}$ & $\mathbf{p}$ \\
\hline \multirow{3}{*}{ Work Values } & $20-30$ & 3.56 & 0.19 & \multirow{3}{*}{3.94} & \multirow{3}{*}{$0.02^{*}$} \\
\hline & $31-40$ & 3.49 & 0.19 & & \\
\hline & $41 \&$ above & 3.59 & 0.19 & & \\
\hline \multirow{3}{*}{ Work Environment } & $20-30$ & 3.31 & 0.23 & \multirow{3}{*}{5.58} & \multirow{3}{*}{$0.01^{*}$} \\
\hline & $31-40$ & 3.41 & 0.17 & & \\
\hline & $41 \&$ above & 3.44 & 0.20 & & \\
\hline Work Interaction & $20-30$ & 3.44 & 0.20 & \multirow{2}{*}{14.58} & \multirow{2}{*}{$0.00^{*}$} \\
\hline \multirow{4}{*}{ Work Activities } & $41 \&$ above & 3.11 & 0.34 & & \\
\hline & $20-30$ & 3.40 & 0.37 & \multirow{3}{*}{20.51} & \multirow{3}{*}{$0.00^{*}$} \\
\hline & $31-40$ & 3.32 & 0.21 & & \\
\hline & $41 \&$ above & 3.59 & 0.29 & & \\
\hline
\end{tabular}

*Significant at 0.05 alpha level of significance.

On work activities, data revealed that the mean score of the employees aging 41 years old and above significantly varied from the mean scores of employees aging 20 to 30 years old. A significant difference was also noted between those who are 41 years old and above and 31 to 40 years old.
However, mean scores obtained by employees whose ages range between 20 to 30 years old did not significantly differ from the average scores obtained by employees aging 31 to 40 years old. These results could mean that differences in work activities can be more felt among older employees. 


\subsubsection{According to Tenure}

Table 8 reveals a significant difference in the preferences of the employees on work values $[\mathrm{F}(3,142)=8.23,0.00<.05]$, work environment $[\mathrm{F}(3,142)=9.54,0.00<.05]$, work interaction $[\mathrm{F}(3,142)=14.07,0.00<.05]$, and work activities $[\mathrm{F}(3,142)=10.41,0.00<.05]$ when they are grouped according to tenure.
Furthermore, Post hoc comparisons using the Tukey HSD test revealed that this significant difference is prominent among the longest-staying employees and those who are in their first 1 to 5 years with the school but not significantly different among younger groups of employees (1-5 vs. 6-10 and 6-10 vs. 11-15).

Table 8. Differences in the preferred work values, environment, interactions and activities of the employees when they are grouped according to tenure.

\begin{tabular}{|c|c|c|c|c|c|}
\hline & Tenure (in years) & Mean & SD & $F_{(3,142)}$ & p \\
\hline \multirow{3}{*}{ Work Values } & $1-5$ & 3.56 & 0.15 & \multirow{4}{*}{8.23} & \multirow{4}{*}{$0.00^{*}$} \\
\hline & $6-10$ & 3.50 & 0.19 & & \\
\hline & $11-15$ & 3.44 & 0.15 & & \\
\hline \multirow{5}{*}{ Work Environment } & $16 \&$ above & 3.69 & 0.15 & & \\
\hline & $1-5$ & 3.41 & 0.21 & \multirow{4}{*}{9.54} & \multirow{4}{*}{$0.00^{*}$} \\
\hline & $6-10$ & 3.55 & 0.18 & & \\
\hline & $11-15$ & 3.28 & 0.19 & & \\
\hline & $16 \&$ above & 3.32 & 0.24 & & \\
\hline \multirow{3}{*}{ Work Interaction } & $1-5$ & 3.50 & 0.21 & \multirow{5}{*}{14.07} & \multirow{5}{*}{$0.00^{*}$} \\
\hline & $6-10$ & 3.60 & 0.16 & & \\
\hline & $11-15$ & 3.27 & 0.21 & & \\
\hline \multirow{5}{*}{ Work Activities } & $16 \&$ above & 3.38 & 0.15 & & \\
\hline & $1-5$ & 3.40 & 0.32 & & \\
\hline & $6-10$ & 3.58 & 0.18 & \multirow{3}{*}{10.41} & \multirow{3}{*}{$0.00^{*}$} \\
\hline & $11-15$ & 3.20 & 0.17 & & \\
\hline & $16 \&$ above & 3.29 & 0.18 & & \\
\hline
\end{tabular}

*Significant at 0.05 alpha level of significance.

In terms of work interaction, the preferences of the employees significantly differed across groups except between employees with a tenure of 1 to 5 and 6 to 10 years, and between 1 to 5 and 16 years and above years of service.

Finally, on work activities, data showed that there is a significant difference in the preferences of employees across groups, except for those between 1-5 years of tenure and 16 years and above, and between 11-15 years of tenure and those with 16 years and above.

\subsubsection{According to Nature of Work}

Results presented in Table 9 reveal that when grouped according to their nature of work (teaching or non-teaching), a significant difference exists in the employees' preferences on work environment, work interaction, and work activities. However, they seem to be held together by the same work values.

Table 9. Differences in the preferred work values, environment, interactions and activities of the employees when they are grouped according to nature of work.

\begin{tabular}{|c|c|c|c|c|c|c|}
\hline & Nature of Work & Mean & SD & df & t & $\mathbf{p}$ \\
\hline \multirow{2}{*}{ Work Values } & Non-Teaching & 3.56 & 0.15 & \multirow{2}{*}{144} & \multirow{2}{*}{0.90} & \multirow{2}{*}{0.37} \\
\hline & Teaching & 3.54 & 0.17 & & & \\
\hline \multirow{2}{*}{ Work Environment } & Non-Teaching & 3.32 & 0.14 & \multirow{2}{*}{144} & \multirow{2}{*}{-4.07} & \multirow{2}{*}{$0.00^{*}$} \\
\hline & Teaching & 3.45 & 0.20 & & & \\
\hline Work & Non-Teaching & 3.36 & 0.24 & \multirow{2}{*}{144} & \multirow{2}{*}{-4.60} & \multirow{2}{*}{$0.00^{*}$} \\
\hline Interaction & Teaching & 3.52 & 0.18 & & & \\
\hline Work Activities & Non-Teaching & 3.32 & 0.34 & 144 & -1.99 & $0.00^{*}$ \\
\hline
\end{tabular}

*Significant at 0.05 alpha level of significance.

Teaching and non-teaching employees place spirituality on top of their core values. They also share in common the value of respect, achievement, and balance although the nonteaching personnel have added to this list the value of honesty. For both groups, power is placed at the bottom of the list. It can also be observed that the faculty places a greater value on achievement, independence, influence, and power compared to the non-teaching staff. On the other hand, the non-teaching personnel place higher value on balance, integrity, honesty, and status.
Foremost among the teaching employees is a work environment that is fast-paced and result-oriented, learningoriented and structured. Non-teaching employees prefer that which is high earning, accessible and convenient, predictable, quiet, relaxed, and time-free.

Both groups share the same preference for teamwork, management, and support. Moreover, they share the same preference for work activities that allow them to help others, require them to work on new and innovative ideas, and engage their imagination and creative talents to produce results. 


\subsection{The Employees' Ideal Environment}

The employees prefer a work environment where honesty and fair exercise of leadership prevail. They highly value integrity among the school leaders and expect people within the organization to do their best to reach their goals without taking advantage of others. They also prefer a friendly atmosphere where everyone is given the opportunity to interact and even showcase their skills and talents. The employees wish for an environment where rewards and motivation are highly encouraged. They also consider very important that their workplace is stress-free and that teamwork is apparent among their colleagues. Lastly, the faculty and staff prefer a safe, pollution free, and a clean work environment.

\section{Discussion}

This study revealed that the employees have different preferences in terms of core work values, environment, interaction, and work activities. They place high regard on spirituality, mutual respect, and reaching goals. These are types of work values which can enhance personal well-being and creativity and are characterized by felt motivation, social support and intention, and receptivity of the employees [8].

The employees work best in a work environment that is fastpaced, result oriented, and organized. They interact best when there is a strong support system, cohesiveness, and the spirit of working together for the attainment of a common goal.

They are best tuned in for work activities that allow creativity and sharing of ideas, skills, and talents and bringing in innovative ideas to produce results.

Moreover, the employees' preferences on work values, work environment, work interaction and work activities significantly differ when they are grouped according to age and tenure. This finding implies that the employees' age and tenure influence their preferences on work values, environment, interaction and activities.

In addition, employees who have the shortest and the longest tenure have different preferences in terms of work values, environment, interaction and activities. This finding is supported by Gursoy, Geng-Qing Chi, \& Karadag [18] who found out that the work values of the employees change as years goes by.

This study also revealed that the preferences of the teaching and the non-teaching staff in terms of work environment, interaction and activities significantly vary.

Lastly, their ideal work environment is one that is safe, clean, and pollution-free and where honesty, fairness, integrity, teamwork, and recognition is highly valued.

\section{Conclusion and Implications}

The employees have varied preferences in terms of core work values, work environment, work atmosphere, and work activities. A slight difference in these preferences is present when factors such as gender, age, tenure, and nature of work are considered. However, although individual differences on these aspects are present, a general description of these preferences can be gathered when they are taken as a whole. It can be useful for the administration then to consider the individualities as well as the characteristics that are commonly shared by the employees. The employees' esteemed preference on spirituality, truth, and propriety jives with one of the core values of the University which is Godliness. Such creed reflects a God-fearing attitude that characterizes a conscientious mindset that could ensure high morals and dignified service, an intrinsic factor that could enhance personal well-being and creativity in terms of motivation, social support and intention, and receptivity. Moreover, the employees' preference on mutual respect, openness, and reaching goals as a team could promote cohesiveness, positive interaction, and solidarity. Consideration and sensitivity must be exercised with prudence by the administration to provide the employees the chance to create a balance between their work responsibilities and their personal affairs such as their families and their social life. Bombarding them with too much work at the expense of their family time and social life could lead to negative behavior and less efficient work performance.

The employees' preference on a fast-paced, result-oriented and organized work environment can be beneficial to the administration because it has a workforce that is driven by action and set goals. However, the employees also value financial opportunities and stability when it comes to their job. Job stability within a career field is a result of people finding environments reinforcing and satisfying [19]. Findings of Yousef [20] revealed a significant relationship between job security and job performance; hence, a threat to the employees' job stability could weaken their enthusiasm and drive to perform their jobs at their best. Being recognized for their part and their significant contribution to the organization's success is very important to the employees, particularly for those who have served the administration for a longer time. Tangible efforts must be made to give due recognition to those who deserved it.

Finally, since the employees are tuned in for work activities that allow creativity, sharing of ideas, skills, and talents, and bringing in innovative ideas, it is best that they should be provided with continuous exposure to these activities and that they should be assigned tasks that could maximize their skills and talents.

\section{Recommendations}

Leaning on the findings of this study, the researchers recommend that the school administration should find time to know and understand their employees' individualities and shared characteristics, and give credence to the core values that they value the most. Knowing these about the employees, they could include such considerations every time they come up with decisions involving the faculty and staff. It is also recommended that in giving them extra assignments, they should be assigned to a team where they 
can excel best. An individual aptitude test can be conducted to identify their areas of interest and inclinations. Furthermore, visible efforts must be made to give recognition to the employees where and when it is deemed best. Workshops must also be provided to allow the employees an opportunity to revisit their value system in relation to themselves and others in the organization. Priorities in relation to work must also be reassessed or redefined through these workshops.

\section{References}

[1] Hansman, R. (2010). "Sustainability Learning": An Introduction to the Concept and Its Motivational Aspects (Sep 2010): 2873-2897.

[2] Sherren, K. (2006). International Journal of Sustainability in Higher Education 7.4: 400-413.

[3] Urde, M. (2003). Core value-based corporate brand building", European Journal of Marketing, Vol. 37 Iss: 7/8, pp.1017 $1040 \mathrm{http} / / /$ www.emeraldinsight.com/journals.htm? articleid=853872. Date Retrieved: May 1, 2014.

[4] Cornelissen, J. (2008), Corporate Communication: A Guide to Theory and Practice, 2nd ed., Sage Publications, London.

[5] Franz-Balsen, A., \& Heinrichs, H. (2007). Managing sustainability communication on campus: Experiences from lüneburg. International Journal of Sustainability in Higher Education, 8 (4), 431-445. doi: http://dx.doi.org/10.1108/14676370710823591.

[6] Amabile, T. M. (1998). How to Kill Creativity. Harvard Business Review. PMID: 10185433.

[7] Isfahani, S. S., Hosseini, M. A., Khoshknab, M. F., Peyrovi, H., \& Khanke, H. R. (2015). What really motivates Iranian nurses to be creative in clinical settings? A qualitative study. Global Journal of Health Science, 7 (5), 132-142. Retrieved from

http://search.proquest.com/docview/1667047575?accountid=3 3508 .

[8] Steve, H. (2013). Spiritual Intelligence Improve Creativity Motivation. Project Management Institute. Retrieved from www.pmi.org/.../spiritual-intelligence-impr.

[9] Akinbode, G. A., \& Fagbohungbe, B. O. (2011). Gender, tenure and organizational factors as predictors of job involvement among Nigerian workers. Gender \& Behaviour, 9 (2), 4005-4038. Retrieved from http://search.proquest.com/docview/906339826?accountid=33 508.

[10] Patel, M. K. (1999). A study of the impact of age on job involvement and organizational commitment of nationalized and cooperative bank employees. sch. sagepub. com/ content/ 34/ 2/ 122.full.pdf.

[11] Vecchio, R. P., \& Boatwright, K. J. (2002). Preferences for idealized styles of supervision. Leadership Quarterly, 13, 327342 .

[12] Gambrell, A. D. (2006). An examination of preferred and perceived required work style differences between men and women managers (Order No. 3196721). Available from ABI/INFORM Global. (304908149). Retrieved from http://search.proquest.com/docview/304908149?accountid=33 508 .

[13] Robbins, S. (2009). Organizational behavior. The International Version, 13/E. Pearson Higher Education.

[14] Glass, G. V. \& Hopkins, K. D. (1984). Statistical Methods in Education and Psychology, 2nd Edition. Englewood Cliffs, NJ: Prentice-Hall.

[15] Goforth, C. (2015). Using and Interpreting Cronbach's Alpha. University of Virginia Library Research Date Services + Sciences. Date retrieved: October 27, 2017. Retrieved at $\mathrm{http} / / /$ data.library.virginia.edu/using-and-interpretingcronbachs-alpha/.

[16] George, D., \&Mallery, P. (2003). Reliability test, SPSS for windows step by step: A simple Guide and Reference, $4^{\text {th }}$ Edn., Chapter 18. Retrieved from $\mathrm{http} / / /$ scholar.google.com.ph?scholar?hl=en\&q=George + and + Mallery+\%282003\%29+reliability\&btnG $=\&$ as_sdt $=1 \% 2 \mathrm{C} 5 \&$ as_sdtp=.Accessed 8 August 2015.

[17] Happiness research: Benefits to make staff happy. (2007). Employee Benefits, 53. Retrieved from $\mathrm{http}: / /$ search.proquest.com/docview/224702645?accountid=33 508 .

[18] Gursoy, D., Geng-Qing Chi, C., \& Karadag, E. (2013). Generational differences in work values and attitudes among frontline and service contact employees. International Journal of Hospitality Management, 32, 40-48. https://doi.org/10.1016/j.ijhm.2012.04.002.

[19] Dockins, J. F. (2004). Person-environment congruence, job stability, and job satisfaction: An examination of Holland's theory of vocational personalities and work environments in the nursing profession (Order No. 3127324). Available from ProQuest Nursing \& Allied Health Source. (305039820). Retrieved from http://search.proquest.com/docview/305039820?accountid=33 508 .

[20] Yousef, D. A. (1998). Satisfaction with job security as a predictor of organizational commitment and job performance in a multicultural environment. International Journal of Manpower, 19 (3), 184-194. Retrieved from http://search.proquest.com/docview/231902524?accountid=33 508. 